\title{
Guidelines for Boundary Stratotypes
}

\author{
by John W. Cowie
}

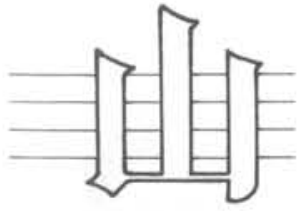

Current activity in the International Commission on Stratigraphy has necessitated the revision of guidelines for submissions on boundary stratotypes, so that decisions will be clear and unequivocal to the specialist stratigrapher and the general geologist alike. This is especially so in view of the many proposals now being prepared for submission. In this article the ICS Chairman reviews both general problems of procedure and technical recommendations for the submission of stratotype candidates. (Ed.)

\section{Introduction}

The International Commission on Stratigraphy (ICS) of IUGS is responsible for the coordination of international stratigraphy, from the earliest part of the Archaean through the Proterozoic and the Phanerozoic: physical, chemical and biological aspects. A major current focus is the selection and definition of boundary stratotypes (Fig. 1). Other branches of stratigraphy are of great importance too, and future changes and additions in the guidelines may well be required.

Following establishment of the Silurian-Devonian Boundary Stratotype in 1972 , a period of great activity by the Commission resulted in the ratification in 1985 by IUGS of boundary stratotypes for Ordovician-Silurian, the Series and Stages of the Silurian System, the Series of the Devonian System, and the Pliocene-Pleistocene (Bassett, 1985).

The submissions to ICS for these and other stratigraphic boundaries illustrate the progress that has been made during the past 13 years. Nevertheless, there is an undeniable variation in the format and quality of the presentations, and guidelines are clearly needed. These must reconcile conflicting demands of freedom of scientific opinion and free choice of methods of correlation, on the one hand, with a reasonably unified procedure, on the other, that ensures that the basic questions are answered.

Boundary definition utilizes a unique point in a rock sequence that represents, if properly selected, a unique instant of time, thus defining unequivocally a standard against which other sequences can be correlated. Unit and composite stratotypes do not fulfill these requirements. The use of biological and palaeontological species in defining boundaries is subjective, for their full range is unknown because of unfinished research, or incompleteness of the geological record. This ean be overcome by using several independent groups of fossils to correlate faunal and floral assemblages.

It can be argued that choices in international stratigraphy should violate historical priority as little as possible: this consideration can often be overridden by the higher priority of going for the best and making progress. Confusing historical precedents may need to be set aside by an authoritative international decision, even though this may violate some established usage.

The International Stratigraphic Guide (Hedberg, 1976) prepared and published by the Subcommission on Stratigraphic Classification contains valuable discussion and recommendations, but it was never adopted by ICS as a statutory policy document. The new guidelines and the recently revised ICS Statutes should be used when and where there is a difference between them and the International Stratigraphic Guide.

\section{Boundary Statotypes:}

Historical geology depends on positional relationships of rock and mineral bodies and identification of evolutionary trends. "The importance of the boundary stratotype lies in its role as a future anchor to which all subsequent correlations ean be tied, even if new palaeobiological or physical methods become available." It is "the only place where we actually know (by definition) that time and rock coincide within our classification" (Holland, 1984, p. 149).

A Global Boundary Stratotype Section and Point (GSSP) is the designated stratigraphic boundary, identified in published form and marked in a particular place in a specific sequence of rock strata. It constitutes the standard for the defining and recognizing the boundary between two named global standard stratigraphic (chronostratigraphic) units. A GSSP is a unique signal for the world geological stratigraphic time scale. A submission to the Commission for a new GSSP cannot be ratified on the basis of a recommended stratigraphic level only: the geographic (type) locality where the stratotype is situated must be exactly and precisely given.

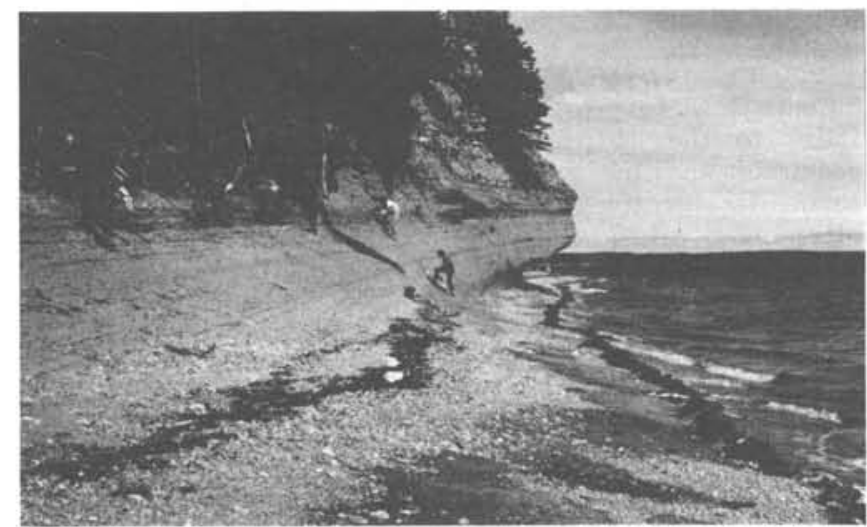

Figure 1: Ordovician strata just below basal Silurian, north of Cape Henry, Anticosti Island, eastern Canada. Photo by C.R. Barnes. 
Insistence on a Boundary Stratotype Point is required in order to define without doubt an instant of geological time. A horizon at the GSSP locality will contain the Point, but the horizon may, when traced laterally, be diachronous, drifting away from the instant of time defined by the point. A correctly selected GSSP should remain fixed in spite of discoveries stratigraphically above and/or below. The main criterion must be that any horizon and point selected is capable of being correlated over wide areas by any or all available methods (Fig. 2),

Correlation must precede the selection of boundary stratotype candidates to a considerable extent, but in practice the sequence may be reversed. The finding of the best level and geographical site may have to proceed together. The choice between two more or less equally suitable boundary levels may be influenced by the availability of a better GSSP for one of them. Improvements in correlation should continue after a boundary stratotype has been selected. Ideally a GSSP would have the maximum possible correlation by magnetostratigraphic and geochronometric methods: this is of increasing importance for future work.

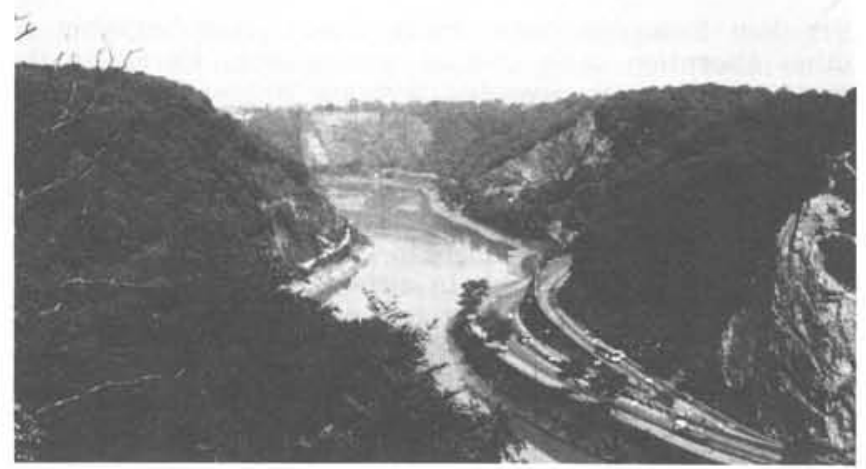

Figure 2: The Avon Gorge, Bristol, southwest England, long regarded as the type section for the British Lower Carboniferous (Avonian). Photo by $G$. Nowlan.

There is no conflict between the GSSP concept and global, isochronous, event stratigraphy. The combination of global environmental change and major biotic ehanges brings together lithostratigraphy and biostratigraphy to provide event stratigraphy. Stratotypes bring stability through an agreed point in rock, representing a unique instant of time (cf. Berry, 1984). The ultimate reference is to rock and not to abstractions.

In the past decade or two much inspiration and guidance in defining a GSSP has been derived by the international geological community from the brilliantly expressed work of the Silurian-Devonian Boundary Committee. One recommendation made by this committee was that the "horizon chosen defines the base of the Devonian, and not necessarily the top of the Silurian. Should it subsequently be shown that the selected horizon is at the level of an undetected time break or hiatus, unrepresented by sedimentation in the section, then the time missing would, by definition, belong to the Silurian" (McLaren, 1977, p. 20).

There is, however, no scientific principle involved in considering the base of a stratigraphic unit any more important than its top. The convention that chronostratigraphic units are defined by their lower boundary (which automatically becomes the upper boundary of the underlying unit) is intended to guarantee the creation of a time seale of contiguous units with no man-made gaps or overlaps. This is also one of the justifications for the preference for boundary stratotypes and not unit or composite stratotypes (Hedberg, 1976).

It is considered preferable to confine nomenclature for ICS candidates to two eategories of stratotype: a global stratotype section and point (GSSP) and an auxiliary stratotype point (ASP). The latter will be particularly useful in drawing upon stratigraphic correlation between markedly different facies, for example New Red Sandstone contrasted with marine Triassic, or Devonian neritic contrasted with pelagic facies. The use of the prefixes holo-, para-, neo-, lecto-, and hypo- to stratotype does little or nothing to assist in the definition of a GSSP for the purposes of international acceptance. Workers may, for their own purposes, wish to use such prefixes, but for the present at least, ICS will not ratify them.

Supplementary sections furnishing additional elements of correlation will be helpful and should be published, but "it is not reasonable to expect the Commission presently to

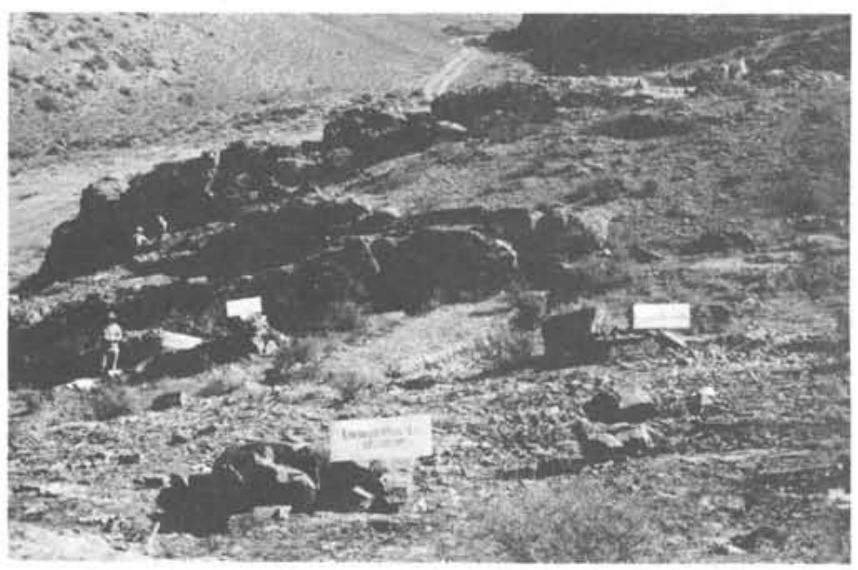

Figure 3: The Cambrian-Ordovician boundary, Batyrbay section, Kazakhstan, labelled for 1984 IGC excursion. Photo by C.R. Barnes.

handle the matter of parastratotypes in a formal way. There is too much other urgent primary work on hand" (Holland, 1984, p. 151). Indeed, ICS still has a great volume of work to get through in the rest of this century and beyond. Matters will be expedited if a plethora of lower status eandidates are not submitted until the main GSSPs, down to stage level, are decided. Similarly, regional stratotypes are the business of the region concerned and not relevant directly to the choice of a GSSP.

\section{Requirements for Boundary Stratotype Submissions}

Submissions to the Commission for a new GSSP must state explicitly the reason for the choice of the boundary level, especially with respect to its correlation potential. A correlation table is required, showing the position of the proposed boundary with respect to both former usage and to the most important markers, and also elarifying rank and relative position of the unit under question.

The reason for the choice of the stratotype locality must also be clearly stated, taking into account palaeogeography, facies, tectonic environment and other relevant factors, including ease of access. Exact data are also required on the location of the type section and point. Submissions should include a detailed description of the type section and 


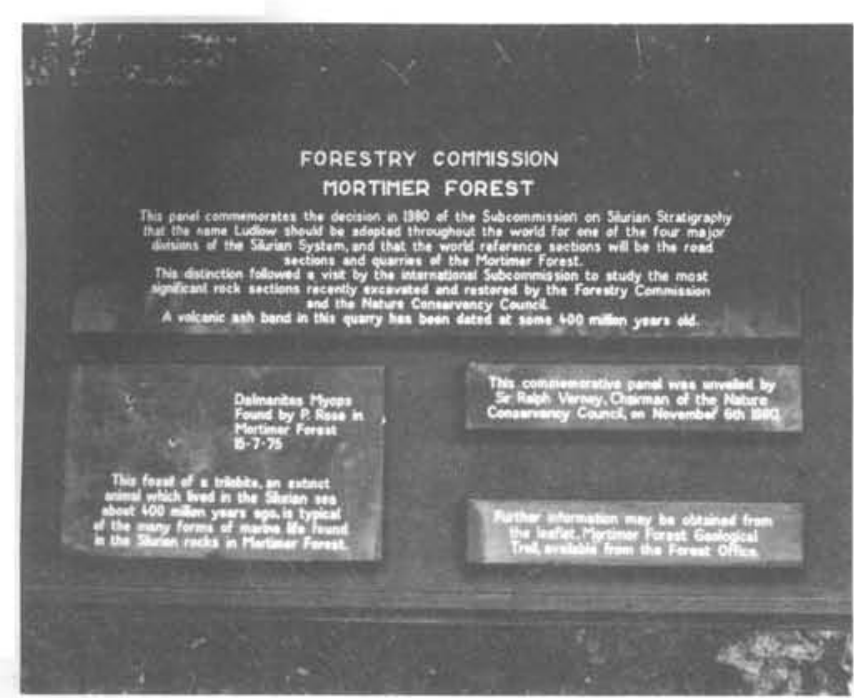

Figure 4: Sign commemorating the 1980 decision of the Silurian Subcommission to adopt the name "Ludlow" for one of the four series of the Silurian. The panel is at Sunnyhill Quarry, Mortimer Forest, Shropshire, U.K., the stratotype location for the base of the Ludfordian Stage (upper stage of the Ludlow Series). Note the missing specimen of Dalmanites myops. Photo by G. Nowlan.

point with a large-scale vertical section showing details of all relevant stratigraphic data: lithology, range of index fossils, magnetostratigraphy and geochronometry.

The relationship of the stratotype section and point sequence to globally significant marker horizons in the immediate and accessible region should be shown (Fig. 3). These include, for example, faunal or floral zone assemblages stratigraphically above or below the stratotype point and climatic markers such as tillites. Long-range, preferably global correlation must precede - and accompany definition of a boundary. The choice of an appropriate level for the point is only possible in the presence of a marker horizon that has proved to be isochronous within the limits of precision attainable by stratigraphic methods. Auxiliary marker horizons as close as possible to the boundary level will give good approximate statigraphic positioning where the primary marker is missing.

Continuity of sedimentation should be demonstrated through the boundary interval - preferably a marine succession without major facies change. A continuous monofacial section will reduce possible errors resulting from stratigraphic gaps and biostratigraphic limitations. Completeness of exposure is also a requirement. The candidate should not be in an isolated position, but it should be in a succession that can be followed easily above and below the GSSP, and preferably laterally as well. An adequate thickness of sediments should be present.

An abundance and diversity of well-preserved fossils is also necessary. Appearances and disappearances of single fossil species can be expected to be diachronous and therefore a bad guide for the location of a GSSP. Multispecies fossil zones may be preferable, and it would be ideal to exclude from consideration taxa that are palaeoecologically tied to a particular facies, though all fossils are to some extent facies controlled. In order to minimize possible effects of environmental controls on different fossil groups, recognition of the boundary level should be based on all available faunal and floral data.
Ideally, selection of a point within an evolutionary lineage is desirable, but recognition of such lineages can be subjective and not necessarily more accurate than the recognition of a particular assemblage zone. Weddige and Ziegler (1979) have given the case for using a single species taken out of a phylogenetic lineage, with its predecessor and successor known in detail, as the biological way (autochronology) of approaching a boundary free of ecological, facial or sedimentary disturbing effect.

The candidate GSSP should be located in a facies favourable for the development of widespread, reliable and timesignificant eorrelation horizons. It should not be in or close to conglomerates, breccias, olistostromes, turbidites or remanie deposits, so as to exclude, as far as possible, variation of chronostratigraphic or chronometric age within the stratotype section near the point. Even if at the present stage of research, for example, fossils in derived blocks and surrounding matrix appear to be of the same age, the danger exists that new techniques or new finds might discriminate between the blocks and matrix, introducing an unacceptable imprecision in the future. Even the "model" decision on the Silurian-Devonian Boundary has had, retrospectively at least, its weakness. The GSSP here was placed within a turbidite on the basis of the "first" occurrence of a species. Nevertheless, it is the first and longest lived GSSP, and the boundary decision is internationally accepted.

Freedom from structural complication, metamorphism or other alteration is an obvious requirement. Currently the question of exotic accreted terrains is pressing, but the problem of the relationship between present and past position may not adversely affect global stratigraphy. Likewise, freedom from unconformities is essential in a GSSP: a too obvious boundary should be suspect. This may be due to a marked change in lithology or a prominent change in fauna or flora. In either case the change may imply a time break, making this an unsuitable horizon at which to fix any time definition. No disconformities, unconformities, cryptic paraconformities or time-breaks in sedimentation any longer than a brief diastem can be tolerated close to a GSSP.

Amenability to magnetostratigraphy and geochronometry are also desirable characteristics. Although these are mentioned last, they are probably the most important factors for future work. Some would argue that no GSSP should be accepted without one or both. Submissions should specify the method used for the actual marking of the GSSP and particularly the actual stratotype point - "the golden spike." This should be a permanent artificial marker, but described in position so that removal by vandals or others does not prevent accurate restoration or replacement .

Sites for GSSP must be accessible and have the potential for conservation. However, if access to an important outerop is too easy and unrestricted, it may be destroyed by excessive collecting, vandalism or plunder (Fig. 4). A stratotype in a large disused quarry may seem ideal until planning permission is given to use it as a garbage dump. A problem for conservation and access may be rapid weathering and erosion caused, for example, by heavy rainfall forming mud-flows from a nearby marly sequence. Frost may form screes, which can soon cover an outcrop, and outcrops on sea coasts may be subject to very rapid erosion.

There must be no insuperable physical or political obstacles to access; geologists from any country must be able to visit the site without great expense and ideally without much bureaucracy. Although it is difficult for any nation or organization to guarantee access and preservation indefinitely, total accessibility must assume considerable importance, so that a reasonable amount of collecting can be done at a stratotype section (Fig. 5). If there is some prestige and responsibility in being "host" to a GSSP, then that may in itself guarantee access and conservation. If a 
GSSP becomes inaccessible in the future, this would be a very powerful argument for a reassessment of the geographic location.

In reality, there is probably no GSSP that ean satisfy all the desired criteria. Moreover, stratigraphy is a practical subject and must be responsive to the needs of working geologists (Fig. 6). Because of their multiplicity and the variation in circumstances through the geological time-scale it would be unwise, or impossible, to specify which criteria are essential and which are desirable. Compromise seems inevitable if progress is to be made with the global stratigraphic scale. In the Phanerozoic, and for the Precambrian-Cambrian Boundary also, the prime "polarity" factor is biological evolution, and boundaries will normally have chronostratigraphic and biostratigraphic guidance. However, in the Proterozoic and Archaean, the main guides at present will be chronometric.

\section{Deciding on a GSSP}

The primary responsibility for approval of a GSSP candidate rests with the Commission, which consists of its officers (the Bureau, normally composed of a Chairman, Past Chairman, two Vice Chairmen, and the Secretary General) and the Chairmen of the Subcommissions. Members of the Commission and its bodies are selected for their expertise and are not delegates of their nation, organizations, associations or any other bodies.

Membership should have a wide geographic spread, except in the more limited Regional Committees. As MeLaren so clearly argued (1977, p.24) "The principle to be learned here is that in this kind of a committee (Silurian-Devonian Boundary Committee) there must be no delegates who represent a particular point of view from a 'school', society or nation. It is only by interacting among themselves, with freedom to change their minds that there can be any possibility of reaching an agreement."

Once the Commission is persuaded there is a need for a special study, an appropriate Committee, Working Group or Subcommission will be set up, and by consultation a con-

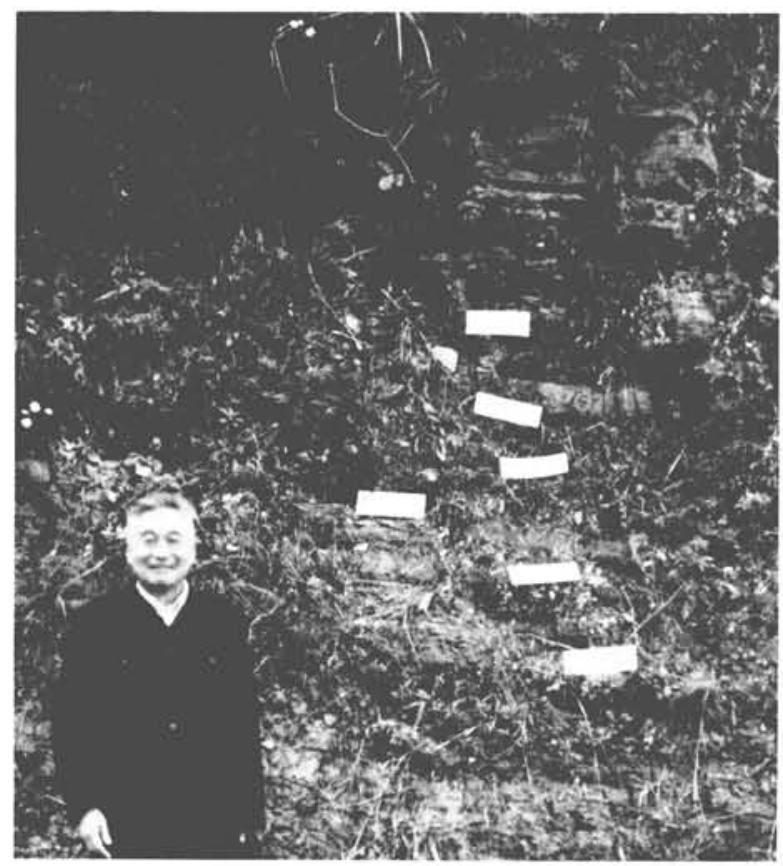

Figure 5: Professor Mu En-Chi (Academica Sinica, Nanjing) in front of an Ordovician-Silurian section, Wangjaiwan near Yichang, Yangtze Gorge region, China. Photo by C.R. Barnes. vening Chairman will be asked by the ICS Bureau to convene it. Once the founding Voting Members have been recruited, they and their elected officers are submitted to the ICS Bureau for approval, together with the list of Voting Members. Corresponding (non-voting) Members can later be recruited without recourse to ICS for approval. Intersystem Boundary Working Groups (independently responsible to ICS and with their own financial allocation) and Intrasystem Boundary Working Groups of a Subcommission should normally conclude their work within a time not exceeding eight to nine years from their initiation. However, submissions from ICS bodies of proposals for ICS approval and subsequent ratification by IUGS can be dealt with at any time, using correspondence and postal ballot.

Discussion at a plenary session of an ICS body should lead to a selection of not more than three candidates to be put to a postal ballot of all Voting Members of that body. The plenary session must be advertised, at least a year in advance, and should be held where all members have convenient access. Any votes taken of those present at the plenary ean be circulated for information but have no mandatory status: the substantive measure is the postal

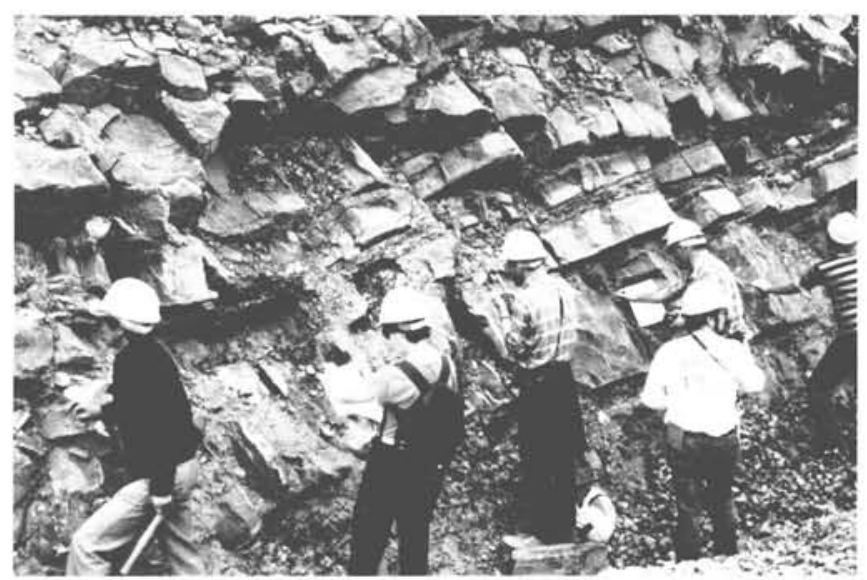

Figure 6: Biostratigraphers examine Visean strata at Kersdown Quarry, northeastern Devon, U.K. Photo by G. Nowlan.

ballot. It should be made clear in eirculated information the proportions of Voting Members, Corresponding Members and guests, with the voting numbers separately itemized.

Ideally the postal ballot should be for only one candidate at a time. If there are two or three candidates then these should be reduced to one by a preliminary postal ballot. The final postal ballot must be YES or NO for one eandidate decision. The Chairman and Secretary-General of the ICS body should conduct the postal ballot, supplying full and adequate documentation (including reports on plenary sessions) to each Voting Member.

In order to proceed then to a formed submission to ICS, the vote in the Subcommission, Committee or Working Group should achieve a $60 \%$ majority of the total vote of Voting Members. Genuine declared abstentions can be excluded from the calculation of this majority. The Bureau will, if appropriate, ensure that the decisions taken are acceptable to the flanking Subcommissions (X system and $\mathrm{Y}$ system, for example) before proceeding to the next stage. In exceptional circumstances, votes of the flanking Subcommissions may be taken by postal ballots under the supervision of ICS. The motive at this stage is to ensure a fair decision and not to challenge scientific points. 


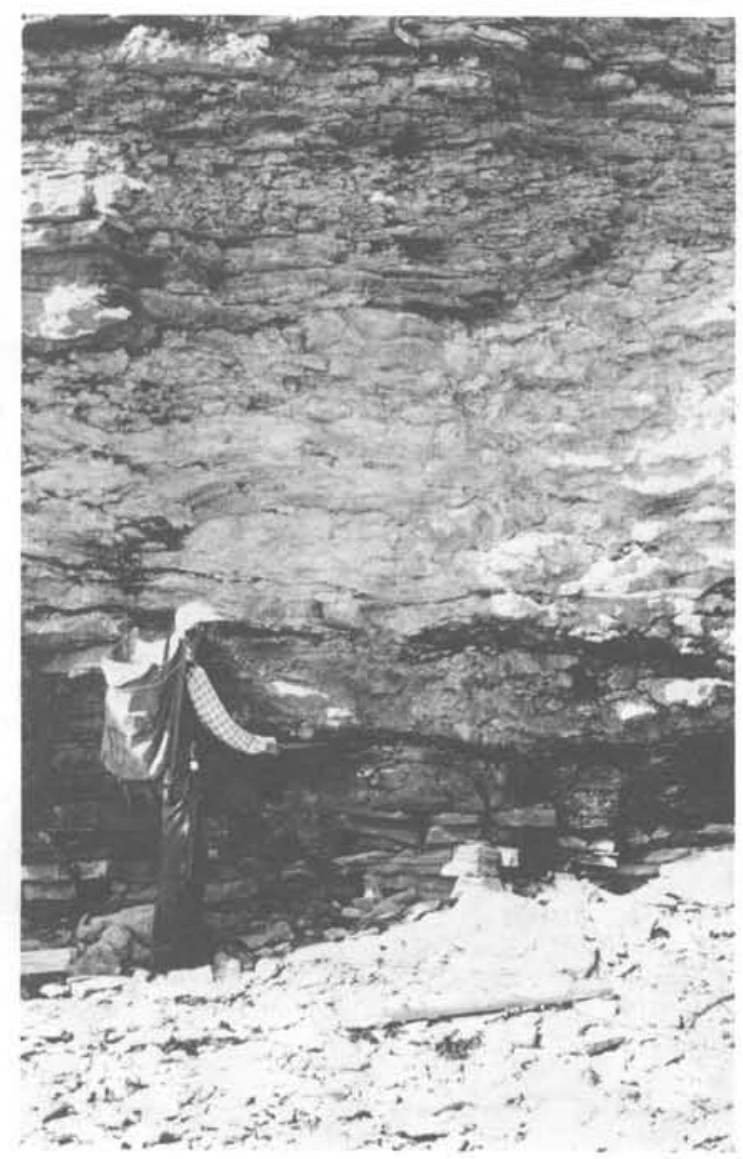

Figure 7: The Ordovician-Silurian boundary, as defined by conodonts, behind man's head. Limestones of Cape Henry, Anticosti Island, eastern Canada. Photo by C.R. Barnes.

Having received the necessary mandate, the officers of the ICS body involved prepare a submission to be sent to the Bureau, for checking against the guidelines. After processing and possible amplification, a postal ballot of all Voting Members of the whole parent International Commission is taken, requiring a majority of $50 \%+1$ votes for approval. The submission will then be sent to the Executive Committee of IUGS for final approval.

If ratification by the Union Executive is to be completed before or during the next International Geological Congress, a Submission deadline date to the ICS Bureau of 8 months before the Congress must be met. Once approved by IUGS, the decision will be formally promulgated. In 1985, this was done in the official IUGS magazine Episodes (Bassett, 1985, and this procedure is expected to continue). A full report should be published in a widely circulated research journal.

\section{Changing a GSSP}

One of the main aims of the Boundary Stratotype procedure of ICS is to attain a common language of stratigraphy that will serve geologists worldwide and avoid petty argument and unproductive controversy. Development of a standard global stratigraphic scale that is stable for a considerable period of time is the goal. The GSSP is unique and should not be subject to competition from "failed candidates" or "syntypes" after it has been decided upon by ICS and IUGS (Fig. 7). Otherwise international acceptance, prestige and respect for GSSPs will be delayed and may be diluted.
Nevertheless, a Boundary Stratotype Point can be changed if a strong demand arises from further important research. In the meantime, it will give a stable point in time from an actual point in rock. To be considered by ICS, such a change requires support from $60 \%$ of the Voting Members of the Commission body responsible for the Boundary, and a simple majority of the Voting Members of ICS itself.

Changes can also be set in motion by the Commission if a majority $(50 \%+1)$ of its Voting Members support the setting up of a new Working Group. Only in very exceptional situations will this be entertained before the second International Geological Congress after the ratification of a GSSP (at present the 1992 IGC likely to be held in Japan). Such circumstances could include permanent destruction or inaccessiblity of an established stratotype, or clearly agreed upon violation of accepted stratigraphic principles.

Acknowledgements: This article is based on a longer paper entitled "Guidelines and Statutes of the International Commission on Stratigraphy" being published (1986) in the Courier Forschungsinstitut Senkenberg. The guidelines were drawn up with the advice of W. Ziegler, A.J. Boucot, M.G. Basssett, and J. Remane of the Commission's Bureau.

Dr. John W. Cowie (Dept. Geology, University of Bristol, Bristol, BS8 1TR, U.K.) is Chairman of the IUGS International Commission on Stratigraphy. His research concerns late Precambrian and lower Palaeozoic stratigraphy, palaeontology and geochronology, particulary in Greenland, the Canadian Aretic, and northern Scotland.

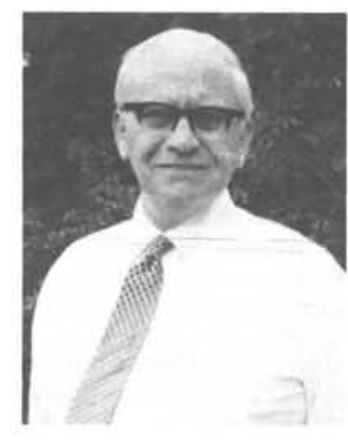

\section{References}

Bassett, M.G., 1985. Towards a "common language" in Stratigraphy. Episodes vol. 8, no. 2, p. 87-92.

Berry, W.B.N., 1984. The Cretaceous-Tertiary boundary the ideal geologic time seale boundary? Newsletters on Stratigraphy, vol. 13, no. 3, p. 143-155.

Hedberg, H.D. (ed.), 1976. International Stratigraphic Guide. John Wiley, New York, London, 200p.

Holland, C.H., 1984. Steps to a standard Silurian. Proceedings of the 27th International Geological Congress, Moscow 1984 , vol. 1 Stratigraphy, VNU Science Press, Utrecht, The Netherlands, p. 127-156.

McLaren, D.J., 1977. The Silurian-Devonian Boundary Committee: A final report. In: The Silurian-Devonian Boundary. A. Martinsson (ed.), IUGS Series A, no. 5, Schweizerbart'sche Verlagsbuchhandlung, Stuttgart, p. 1-34.

Weddige, K. and Ziegler, W., 1979. Evolutionary patterns in Middle Devonian conodont genera Polygnathus and Icriodus. Geologica et Palaeontologica, vol. 13,3 A bb, $\overline{\text { Marburg, }}$ p. $157-164$. 